\title{
Iceland spar and its legacy in science
}

\author{
L. Kristjánsson \\ Institute of Earth Sciences, University of Iceland, Sturlugata 7, 101 Reykjavík, Iceland \\ Correspondence to: L. Kristjánsson (leo@raunvis.hi.is)
}

Received: 13 February 2012 - Revised: 25 April 2012 - Accepted: 27 April 2012 - Published: 16 May 2012

\begin{abstract}
In the late 17th century, Rasmus Bartholin and Christiaan Huygens investigated a curious optical property of crystals found at Helgustaðir in Eastern Iceland. This property which has been called double refraction, revealed in the 19th century a new aspect of light which turned out to be very useful as a probe of the internal structure of matter. Clear specimens of these crystals, an unusually pure variety of calcite, have since around 1780 been known as "Iceland spar". Few if any other localities yielding calcite crystals of comparable size and quality were discovered before 1900, and no alternatives for use in precision optical instrumentation were developed until the 1930s. Hundreds of tons of calcite were exported from Helgustaðir, mostly between 1850 and 1925 . However, little information has been found on trading routes for the material of optical quality, so that some enigmas remain regarding its supply-demand situation. A study of the scientific literature in the period up to 1930 has revealed that results obtained with the aid of Iceland spar accelerated progress within the earth sciences (in mineralogy and petrology), physics, chemistry, and biology, even by decades. This has also influenced the development of technology and of medicine in various direct and indirect ways.
\end{abstract}

1

In the mountainous fjord area of Eastern Iceland, there lies a small quarry on the land of a farm named Helgustaðir. At this site, the local inhabitants collected crystals of calcite: the first definite records of their presence there date from 1668. Their peculiar optical characteristics were described in important treatises by Bartholin (1669) and Huygens (1690). From around 1780, the crystals from Iceland were commonly called "Iceland spar", "spath d'Islande" or "isländischer Doppelspat(h)". The German name refers to their double refraction (Fig. 1), i.e. the property of splitting an incident light ray in two directions. This property characterizes the crystalline state, except for crystals belonging to the cubic system of symmetry such as halite (rock salt, $\mathrm{NaCl}$ ), fluorite, and diamond. Research by the author since 1995 on the applications of Iceland spar has revealed that it served in valuable functions across a wide range of experimental situations in the physical and natural sciences. Provisional findings of this research were reported by Kristjánsson (2002).

Kristjánsson (2003) presented a concise history of the Helgustaðir site. Until 1850, specimens of spar crystals were presumably transported abroad by Danish traders, by fishermen from northern France, and by occasional foreign visitors exploring the region. From 1850, commercial quarrying at Helgustaðir for export took place at intervals. A much less accessible location at Hoffell in Southeastern Iceland, discovered in 1910, also delivered minor quantities of Iceland spar. Very little optical-quality material seems to have been recovered from either of these sites after 1925. Uncertainties still remain as discussed in Sect. 9 below, regarding the means by which Iceland spar crystals reached their various users abroad.

An extensive report on the many roles of Iceland spar in science during 1780-1930 (Kristjánsson, 2010) is accessible on the Internet. For more details of the topics discussed in the present brief resumé, readers are referred to the report. Its annotated bibliography of over two thousand publications is a tiny fraction of the relevant scientific literature of that century and a half; the references quoted here are in turn a small but hopefully representative sample from that bibliography.

Not much is known about the origin of the Iceland spar deposit at Helgustaðir. According to the only published geological study of its surroundings (Walker, 1959), the calcite 


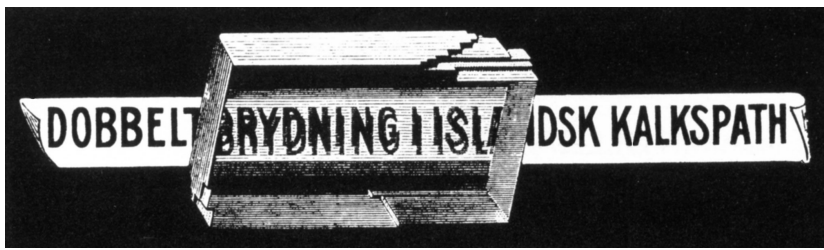

Figure 1. Double refraction in a cleavage rhombohedron of Icelandic calcite. The relative displacement of the images is about a tenth of the specimen thickness. Such pictures appeared in various 20th century European textbooks on optics; this one was reproduced in the Danish magazine Naturens Verden (Vol. 69, p. 363, 1985).

crystals were formed around 11 million years ago, by hydrothermal alteration of basalt lava flows within a large volcanic center.

\section{The unique role of Helgustaðir}

Crystals of naturally occurring minerals have been much studied and made use of in science through the centuries. Some of these minerals have valuable mechanical, optical, electrical, thermal or magnetic properties. In physics for instance, the minerals with the most widespread experimental uses have probably been pure quartz (rock crystal), diamond and calcite (mostly Iceland spar). In contrast to the other useful minerals, which were recovered at many localities, the Helgustaðir site seems to have remained the chief source of Iceland spar crystals for scientists up to 1900 (when occasional shipments from Crimea were reported) or even to 1920 (Hughes, 1937).

The most important characteristic of calcite was the unusually large difference between the maximum and minimum value of its refractive indices. In treatises and textbooks describing double refraction and the optical properties of crystals in general, Iceland spar has been most commonly chosen as a type example (Fig. 1). Some specimens from Helgustaðir were rhombohedra (parallelepipeds) having the fundamental shape of their crystal class (Fig. 1 and lower part of Fig. 2). That form is rarely exhibited alone by calcite crystals from elsewhere (Klockmann, 1903, p. 394). The crystals could reach $15 \mathrm{~cm}$ or more in size, and the best of these were completely transparent and free of flaws, coloring, twinning or inclusions. The uniformity of their angles and unit-cell dimensions, as well as their easy cleavage and very smooth cleavage faces, was appreciated by scientists seeking results unaffected by between-sample variability. Thus, Mascart (1872, p. 196) stated that “...le spath d'Islande est peut-être la substance la plus homogène que l'on puisse se procurer et que les surfaces n'ont pas besoin d'être travaillées avec une trèsgrande perfection...".

The uniqueness of the Icelandic material is reflected in comments in learned journals and books; scores of these are reproduced in Appendix 1A of Kristjánsson (2010).

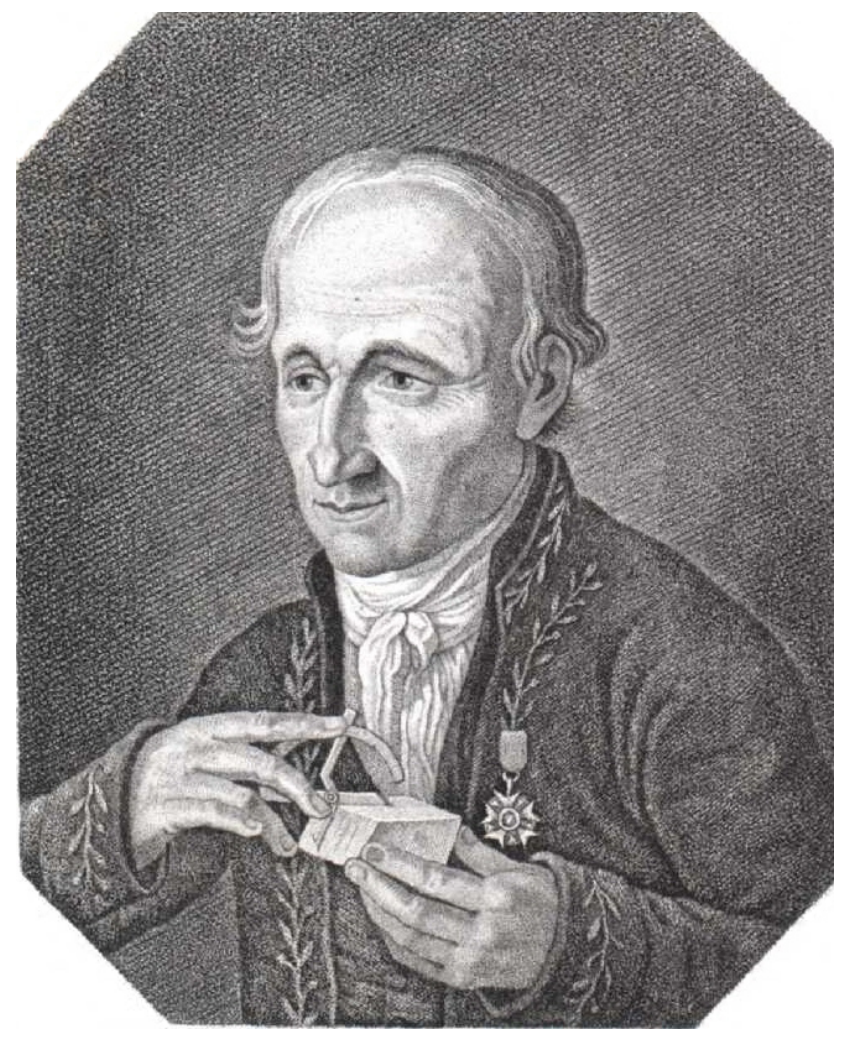

Figure 2. René Just Haüy (1743-1822), abbot and "father of crystallography" pictured measuring a crystal which probably represents Iceland spar. Haüy's interest in the subject was initially aroused when he found that calcite crystals of various shapes could be cleaved to reveal the "forme primitive" of Fig. 1 above.

Bréon (1882) refers to Helgustaðir as the "...localité qui seule a fourni au monde civilisé cette précieuse substance pour les instruments d'optique". G. G. Stokes, the President of the Royal Society of London, states in a letter in 1886 (Appendix 1C of Kristjánsson, 2010) that calcite “...has nowhere to my knowledge, been found in large, clear, regularly crystallized masses except in Iceland". A monograph by Brauns (1903, p. 378) laments that “...es ist noch nicht gelungen, den immer seltener und teurer werdenden klaren isländischen Doppelspat zu ersetzen" in various optical instruments.

Specimens from Helgustaðir were among the chemically purest minerals available from nature, consisting of over $99.9 \% \mathrm{CaCO}_{3}$ (Kristjánsson, 2010, Appendix 2). Frequent use was therefore made of Iceland spar as a reagent in nineteenth-century research in inorganic and physical chemistry, such as on the atomic weights of some elements, on equilibria in solutions, and tests of new analytical methods (Kristjánsson, 2010, Ch. 26). 


\section{Scientific advances promoted by Iceland spar crystals}

Calcite exhibits a greater variety of crystalline forms than any other mineral; for instance, Irby (1878) compiled some 200 examples of these from well-known localities of calcite crystals such as Andreasberg in Germany. Little has on the other hand been published about the crystallography of calcite from Helgustaðir. Nevertheless, research on Iceland spar by scientists like David Brewster and Eilhard Mitscherlich contributed significantly to important discoveries relating to crystallography in the 19th century; indeed, Tschermak (1881, p. 101) referred to Doppelspath as "...der Grundstein unserer physikalischen Kenntnis der Krystalle". These discoveries include:

- Theories of the internal geometry of crystals (as an ordered structure made up of "molécules intégrantes"), and their classification into seven systems, by Haüy (1784; Fig. 2), Bernhardi (1808) and others in the decades around 1800

- Isomorphism (i.e. when chemically different compounds form very similar crystals) and polymorphism (when a chemical compound may form crystals belonging to different systems, depending on conditions)

- The distinction between optically uniaxial and biaxial crystal systems (Brewster, 1819)

- Anisotropy of other physical properties, noted first in the thermal expansion of Iceland spar (Mitscherlich, 1828), later in its magnetic susceptibility, hardness, elastic parameters and thermal conduction. This pointed the way to the application of vector fields in anisotropic materials

- Twinning and other structures within crystals, especially in relation to their mechanical deformation (Reusch, 1868).

Étienne-Louis Malus who noticed in 1808 that a change in the character of light upon its reflection from smooth surfaces was similar to that occurring when light traversed a crystal of Iceland spar, gave the name "polarization" to this change. His discoveries (Malus, 1811) precipitated a rapid expansion in our knowledge of light and light-matter interaction during the 19th century. Already by 1860 , treatment of double refraction and polarized light occupied more than half of the text of some books on physical optics (Billet, 1858-1859). Among important advances in optics in the 19th century where research with Iceland spar played some part, one may mention the following:

- General acknowledgement of the views of Huygens (1690) and Young (1802) that light is a wave rather than a stream of particles
- The conclusion that double refraction and the polarization of light are manifestations of transverse oscillations within the light waves; "linear polarization" refers to light vibrating in a single direction

- Theoretical models of wave propagation in anisotropic solids (Fresnel, 1827), and their experimental confirmation; Augustin Fresnel also derived formulas for the relative intensity of polarized light rays reflected and refracted at boundaries of different materials

- Realization that "heat rays" and "chemical rays" (i.e. infrared and ultraviolet radiation) only differ from visible light in their wavelengths

- Discoveries regarding optical activity (i.e. progressive rotation of the plane of polarization of a light ray) in quartz as well as in many organic liquids and solutions (Biot, 1817)

- Detection of stress-induced birefringence in isotropic solids (Brewster, 1816)

- Various findings on ultraviolet light, to which calcite is more transparent than the glass available in the 19th century; among these were observations of the spectral lines of hydrogen (Huggins, 1880), which led to publication of the Balmer (1885) formula for their wavelengths and later to Niels Bohr's theory on electron orbits in atoms.

\section{Nicol prisms, experiments and instruments}

The main application of Iceland spar from the 1830s onwards was in composite polarizing prisms. Such prisms were first described by William Nicol, and many improved versions appeared later. They can be used both for the production of linearly polarized light (Nicol, 1829), and for measurements of the state of polarization of light. This was important in observations of the many processes involving light: its emission, reflection, refraction, transmission, absorption and especially optical activity, see below. Generally an optical instrument or experimental setup contained two Nicol prisms, and commonly also accessories made from calcite, quartz, mica or selenite (gypsum). The prism employed to polarize the light from an ordinary light source was often the larger one and tended to be made from Helgustaðir crystals, while material from other locations (Beckenkamp, 1915, p. 114) could be used in a smaller prism analyzing the light after its interaction with matter. Attempts at growing artificial calcite or sodium nitrate crystals of sufficient size and quality for Nicol prisms were not successful until the second half of the 20th century. Other devices employed for polarizing of light (primarily thin tourmaline plates and glass reflectors) were only suited for undemanding applications.

Thousands of experiments in optics and related fields of physics, with Nicol prisms as an important component, were 

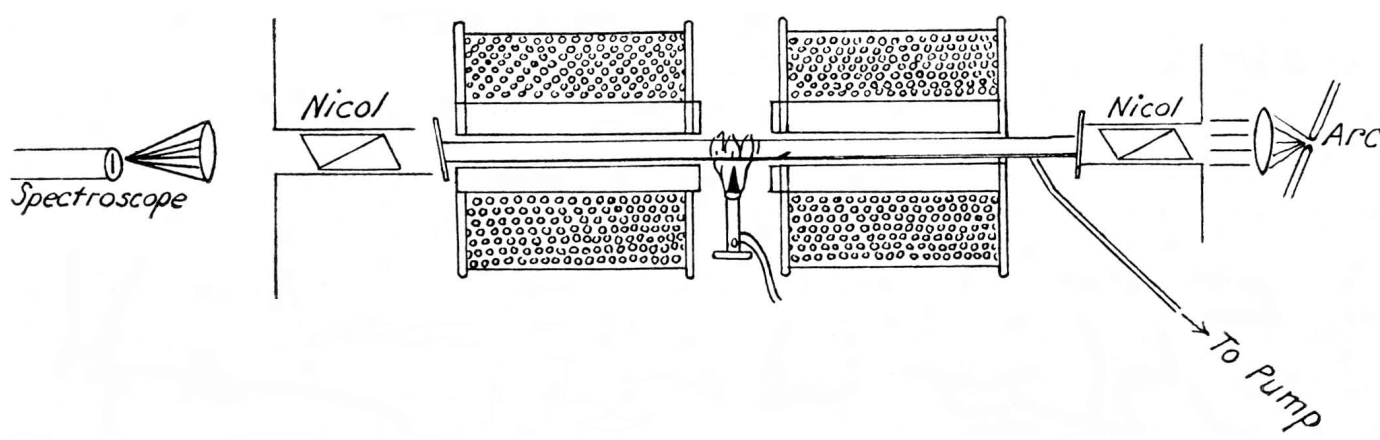

Figure 3. A schematic diagram of an experiment in physics employing Nicol prisms of Iceland spar. In this case, the Faraday effect in hot sodium vapor is being investigated (Wood, 1905). The direction of polarization of a light beam coming from the right is rotated within the vapor by the magnetic field produced by two coils.

carried out during the 19th and early 20th centuries. Discoveries made in some of these experiments have profoundly affected the subsequent development of science. A small selection might include:

- Optical activity induced by magnetic fields in transparent substances (Faraday, 1846; Fig. 3) and in ferromagnetics (Kerr, 1877)

- Beer's (1852) law of light absorption in aqueous solutions

- Research by Tyndall (1869) on light scattering by small particles, leading to Lord Rayleigh's theoretical work on that subject

- The electro-optical effect found by Kerr (1875), used in the early 20 th century for light-speed measurements and studies of short-lived events

- The magneto-optical effect discovered by Zeeman (1897), which provided a key to the application of quantum theory in atomic physics

- The Maxwell effect (flow birefringence), the Pockels electro-optical effect, the Cotton effect (circular dichroism), the photoelectric effect, and many others.

Those instruments incorporating Nicol prisms which were manufactured commercially in large quantities, may be divided into three main types to be dealt with in the following sections. These were:

- Polarimeters for measuring optical activity, and related instruments (ellipsometers, etc.) to establish the state of polarization of a light beam

- Petrographic microscopes and associated equipment (such as stauroscopes, phase compensators and axialangle instruments) for studying the optical parameters of minerals (and, more generally, of crystals)

- Photometers and spectrophotometers, including specialized devices.

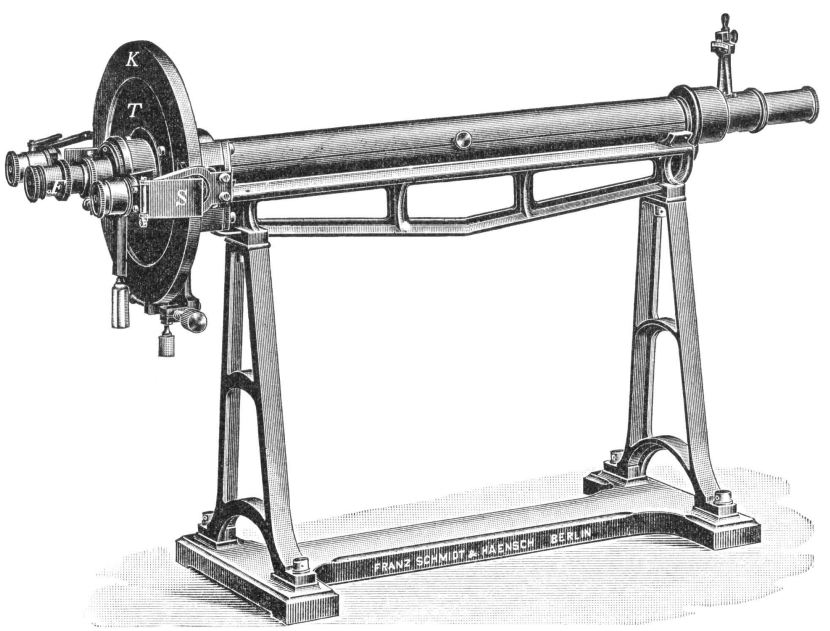

Figure 4. A polarimeter for research on optically active organic liquids and solutions. A liquid sample which is contained in a long enclosed glass tube between two Nicol prisms, rotates the plane of polarization of light passing through. From Struers' (1925) catalog.

\section{Polarimeters}

Polarimeters containing two Nicol prisms were in common use around 1850, both by scientists (e.g. Becquerel, 1849) and in the sugar industry (cf. Pelouze and Fremy, 1850, pp. 337-360). By 1900 they were among the most accurate of all physical instruments (Landolt, 1898, p. VIII; Fig. 4). Their chief application was in the measurement of optical activity which is a characteristic property of many organic liquids and solutions. The contribution of these instruments to organic, inorganic, physical and biological chemistry may be appreciated from the following list of scientific and technical achievements where polarimetry played prominent roles:

- Discovery, purification and characterization of thousands of organic compounds from natural sources, chiefly plants (Landolt, 1898) 
- Laboratory synthesis of many naturally occurring optically active chemicals, new compounds derived from these, and other new chemicals

- Discovery of the connection between optical activity and mirror-image symmetry in crystals (Pasteur, 1848) and subsequently in molecules, leading to the field of stereochemistry and of chirality of structures

- Understanding of the kinetics of chemical reactions (Arrhenius, 1889)

- Diagnosis of diabetes (Biot, 1840) and research on this disease

- Elucidation of the basic structure of mono- and disaccharide molecules, especially by Emil Fischer in 18841895 , and later research on the detailed configuration of these sugars by W. Norman Haworth and many others (see Pringsheim, 1925)

- Analysis of the constituents of carbohydrates such as raffinose sugar, starch, glycogen, cellulose, inulin, and chitin

- Research on the occurrence, properties and interrelations of classes of organic compounds such as amino acids and proteins (Fischer, 1906), glycosides, alkaloids, terpenes and camphors, sterols, nucleic acids, and enzymes

- Synthesis of optically active molecules based on atoms other than carbon, beginning with nitrogen around 1900

- Werner's (1911) confirmation of his theories on "coordination compounds"

- Control of materials and processes in the sugar and fermentation industries from the 1840s onwards (see Bates et al., 1942), including the production of sugars by hydrolysis of starch; the polarimeter "...is the principal and indispensable tool of the sugar chemist..." (Osborn, 1920)

- Knowledge leading to large-scale synthesis of chemicals previously obtained at much greater expense from natural sources

- Detection of adulteration in foods; in the US, progress in that field (led by Harvey W. Wiley) contributed to founding of the Food and Drug Administration

- Research on the optical and electrical properties of metals, semiconducting materials, and thin films (Drude, 1900).

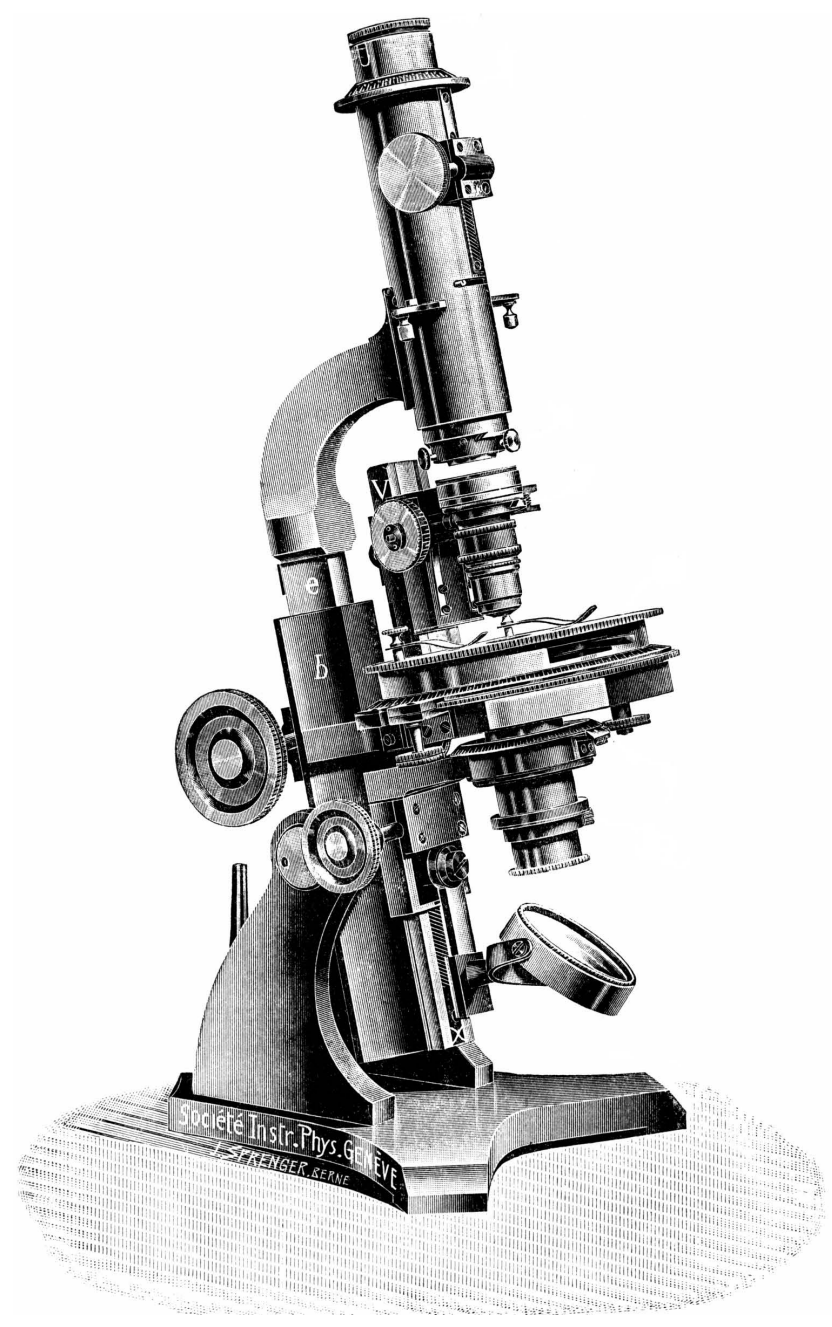

Figure 5. An advanced petrographic microscope, made around 1905. One Nicol prism is below the platform which holds thinsection specimens, and another one is at the top. From Duparc and Pearce (1907).

\section{Microscopes for mineralogy and petrography}

By the late 1840s, microscopes with Nicol prisms or other polarizing attachments were in use by some amateur microscopists (see Pritchard, 1845, pp. 111-120) and a few biologists (Ehrenberg, 1848). However, they were not employed much by geologists until around 1860 when A. Descloizeaux, Zirkel (1863) and others demonstrated their potential for research on thin sections of minerals and rocks. An illustrated account of early types of such microscopes was presented by Kile (2003).

These microscopes (Fig. 5) and auxiliary equipment (Fig. 6) revolutionized many fields of the earth sciences. Among their advantages for geological investigations were (see Vogelsang, 1867; Groth, 1885; Grubenmann, 1887): 


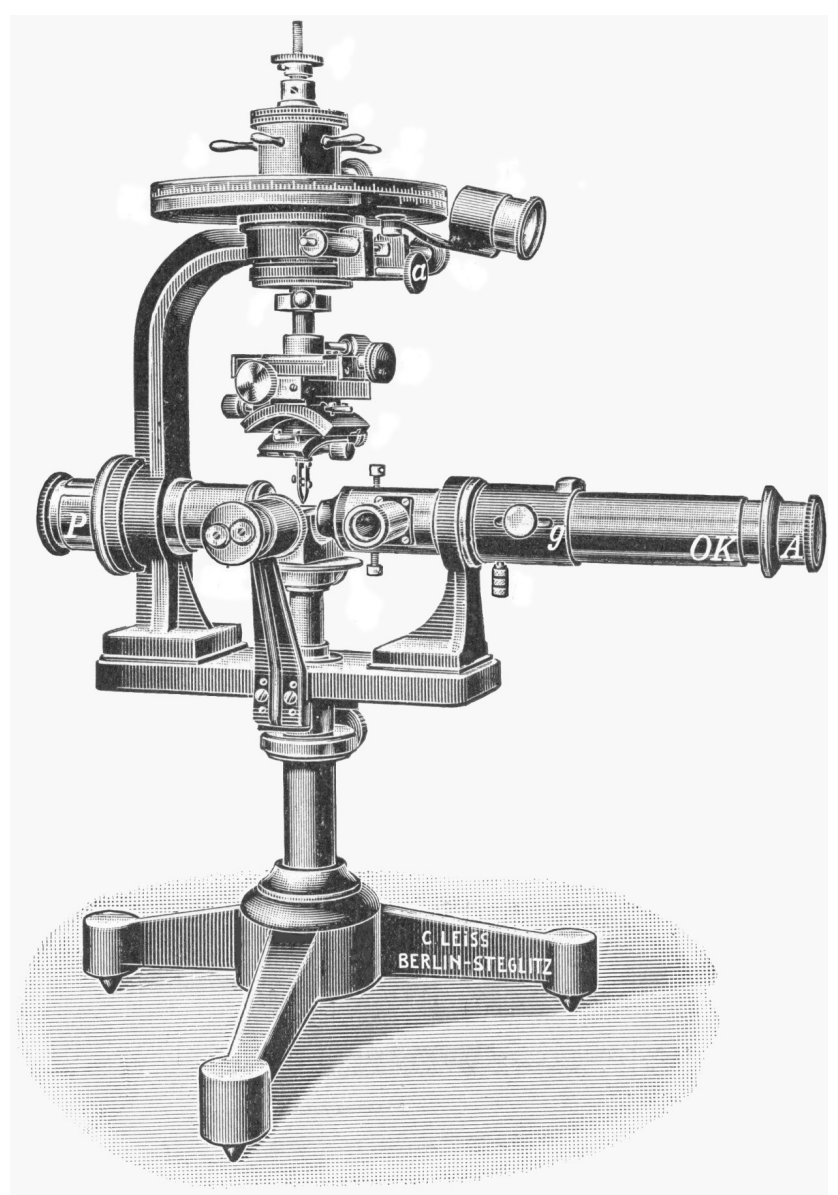

Figure 6. A specialized instrument for measuring the optical properties of single crystals, designed by E. A. Wülfing. Nicol prisms are at $\mathrm{P}$ and $\mathrm{A}$, in the outer ends of the horizontal tubes. Adapted from Leiss (1925).

- Easy differentiation between grains of those minerals which appear very much alike in ordinary light

- Realization that many minerals previously thought to be rare, were in fact common

- Determination of the chemical composition of individual grains (e.g. isomorphous series as in feldspars), even very small ones, from their optical properties

- Observations of zoning, twinning, pseudomorphs, alteration and deformation features

- Studies of high-temperature transformations and equilibria of minerals, using heated stages; laboratory synthesis of minerals and rocks

- Clarification of the provenance of sedimentary rocks

- Observations of associations between minerals, which was useful in prospecting
- Improved understanding of crystallization processes in magmas.

Petrographic microscopes contributed to applied research on many man-made industrial materials like Portland cement, abrasives and refractories, and they were indispensable in studies on liquid crystals which were initiated around 1888 (e.g. Lehmann, 1911-1913). Microscopes of this type were also used to some extent in biology (Schmidt, 1924), for instance in the study of cells, nerve and muscle tissues, invertebrate exoskeletons, and plant fibers. 20th-century developments included reflected-light microscopy on ore minerals and metals.

\section{Photometers}

In the 19th century and until well after the appearance of practical photoelectric sensors around 1910, measurements of light intensity were carried out by visual comparison of an unknown and a standard light source. Light beams from these sources were viewed in juxtaposition, the intensity of one beam being attenuated in some measurable way until they appeared equal. The use of two Nicol prisms in tandem was found to be a convenient and reliable attenuation method, and it was employed in several designs of photometers from around 1850 to 1940 or later. Some were produced commercially, the best known type being the König-Martens spectrophotometer (Martens and Grünbaum, 1903; Fig. 7). Examples of experimental research involving such photometers include:

- The various modes of light emission (fluorescence, black-body radiation, gas and electric lamps, colored flames, etc.)

- Light absorption by solutions of salts and dyes, as well as by blood, colloids, glasses, crystalline materials, and the atmosphere

- Photographic processes and optical phenomena recorded on photographs

- The magnitudes of tens of thousands of stars (e.g. Pickering et al., 1884), including many variable ones.

The Wanner (1902) optical pyrometer, based on the same principles, was manufactured for decades and found extensive use in measuring high temperatures $\left(>1000^{\circ} \mathrm{C}\right)$ in science and industry. Modified polarization photometers were developed for numerically describing and replicating composite colors. Color-blindness and various other aspects of human vision were also studied with the aid of such instruments.

\section{X-ray studies}

In the initial stages of research on X-ray diffraction (from 1912) investigators tended to employ crystals of the cubic 


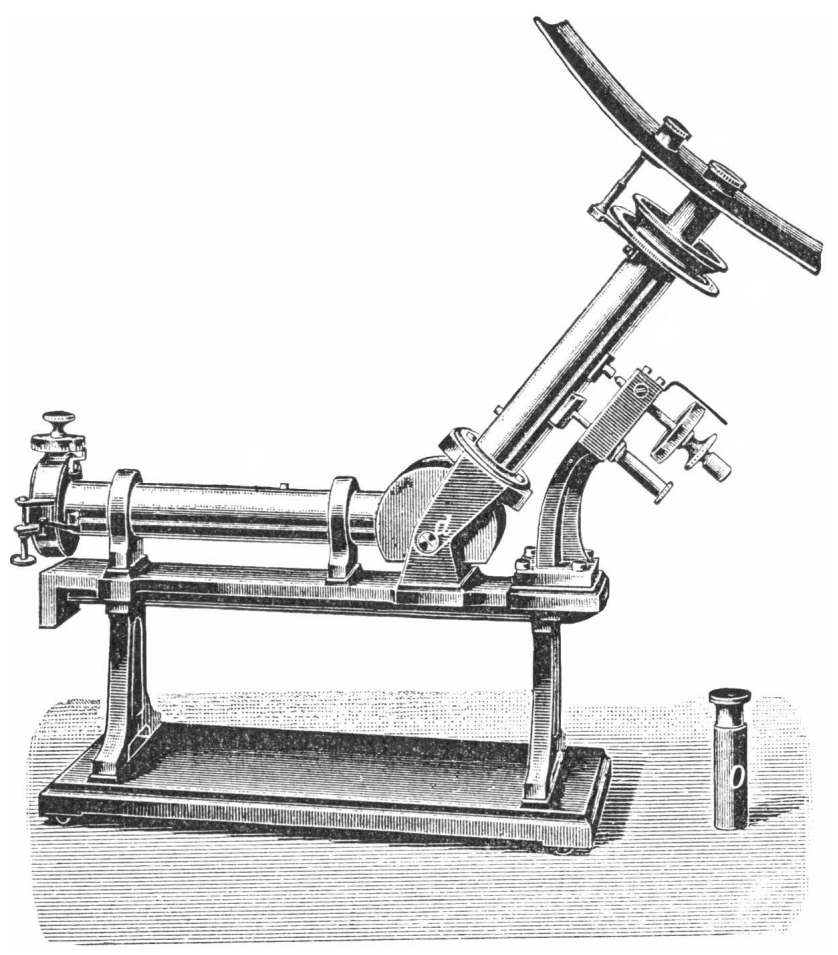

Figure 7. A popular spectrophotometer invented by A. König and improved by F. F. Martens in 1903. The instrument contains two Iceland spar prisms and a glass dispersing prism. From Weigert (1927); a light source and sample platform to the left are not shown.

system such as halite and zinc blende ( $\mathrm{ZnS})$ for wavelength estimates. Soon however, it was realized that calcite was in many respects more suitable for X-ray work. Crystals from Iceland and sometimes also from other regions were therefore involved in early interpretations of diffraction patterns, for instance by Bragg (1915) and Schiebold (1919; Fig. 8). Iceland spar subsequently served as an analyzing standard in X-ray spectrometry until at least 1950 . Papers describing experiments in this field mention in particular its fine cleavage faces (Compton, 1916), the uniformity of its properties between the best specimens, and the high resolution of wavelengths which could be attained. These qualities contributed significantly to the detailed mapping of emission, absorption, and fluorescence spectra for the heavier elements (see Siegbahn, 1924), which in turn yielded accurate data on their electronic energy levels for comparison with theoretical models. Other important projects involving Iceland spar included the evaluation of fundamental quantities like the electron charge and Planck's constant, observations on the refraction of X-rays in materials (Davis and Terrill, 1922), and research on the Compton effect (Mitchell, 1929),

Most of the various crystalline minerals studied by means of X-rays turned out to exhibit a mosaic-like structure to some extent. This precluded the interpretation of diffraction results by a comprehensive method called the dynamical the-

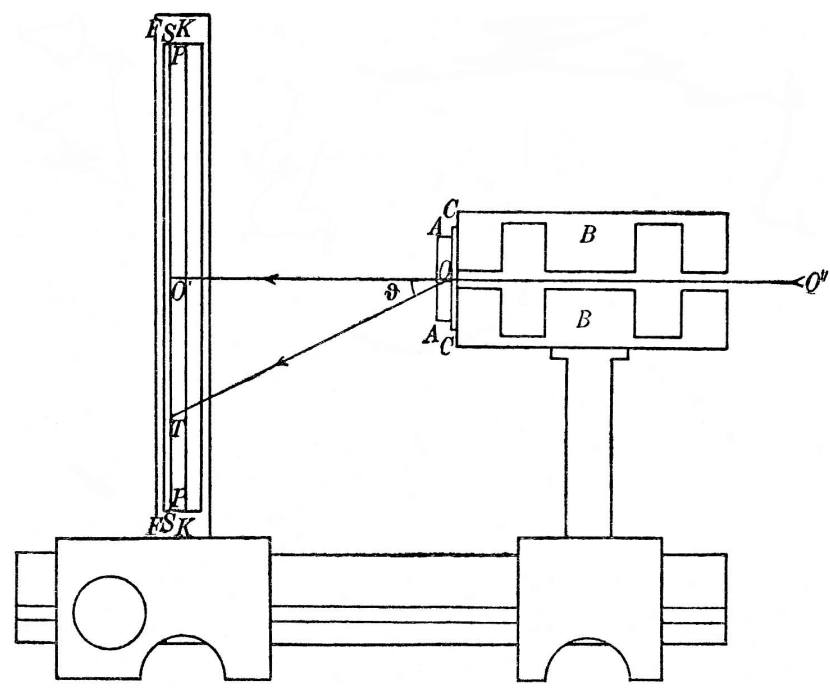

Figure 8. The setup employed by Schiebold (1919) in his research on the detailed structure of calcite by means of X-ray diffraction. The narrow X-ray beam O"O is deflected at various angles $\theta$ by a 1-mm thick crystal plate AA (fixed to the cover glass CC) and is then recorded by the photographic plate PP. BB is a lead screen. Schiebold's specimens were all cut from a "wasserklares Spaltungsrhomboeder von Isländer Doppelspat”.

ory, which only applied to perfectly regular crystal lattices. Some Iceland spar specimens were among the few materials with a sufficiently regular structure to allow testing of this theory (Borrmann, 1950), before perfect synthetic crystals became available around 1955 .

\section{Enigmas of supply and demand}

The writer has not been able to locate much documentation on the logistics and economics of the mining operations, the means of exporting the crystals, their foreign buyers, the manufacture of Nicol prisms, and so on. Enigmas remain with regard to an apparent gap between the production and the consumption of Iceland spar in two different periods, the first one being approximately from 1820 to 1850 . It is generally agreed (Thoroddsen, 1913) that commercial exploitation of the Helgustaðir site was not initiated until 1850; some early travelers (Olavius, 1780) also mention that it took them great effort to recover any crystal specimens there. Yet, advertisements from purveyors of Iceland spar rhombohedra and plates were appearing in scientific journals before 1830 (Albert, 1828). Dove (1835, p. 607) mentions a technician in Berlin “...dessen Nicol'sche Prismen in den Händen vieler Naturforscher sind...", and such prisms had evidently reached quite a wide distribution among European scientists by 1850 . In the Parliament of Iceland one delegate (Hjaltalín, 1875) alleged that foreigners had in the past often pilfered large quantities of crystals at Helgustaðir, even by the shipload. If correct, this could provide at least a partial 
resolution of the supply-demand enigma prior to 1850 . However, the writer has not seen accounts from abroad which might confirm Hjaltalín's claim.

Quarrying efforts by local merchants in 1855-1860 and in 1863-1872 were said (Thoroddsen, 1913) to have recovered 50 and 280 tons, respectively, for export. Only a small proportion of this amount was of optical quality; the remainder may have been mostly used for making caustic lime or other industrial materials. A stockpile of crystals built up by the latter operator, C. D. Tulinius, appears to have satisfied the needs of scientific and educational consumers into the early 1880s at least. In the period between 1855 and 1882, many types of prisms and other preparations of Iceland spar occasionally reaching sizes of $8-10 \mathrm{~cm}$ or more, were advertised for sale by dealers in Europe and the US (Kristjánsson, 2010, Ch. 25). Quarrying was continued on a small scale in 1882 and 1885 by the Government, which was the sole owner of the Helgustaðir farm after 1879. In 1895-1910 the quarry was leased to the above-mentioned C. D. Tulinius and his son.

A second supply-demand enigma applies for the period between the early 1880s and 1910. Two views of this enigma will be presented in the following paragraphs.

In one view we note that the sales of first-class spar were only on the order of 50-120 kg per year according to annual balance statements prepared by the 1895-1910 quarry operators; many of these statements are accessible in the National Archive of Iceland (Kristjánsson, 2010, Fig. 32-1). This may be contrasted with the amount of crystals needed annually as raw material for Nicol prisms in instruments with polarizing optics (as shown in the above Figs. 4 to 7). It must be kept in mind that there was great wastage of spar in the production of Nicol prisms, up to $95 \%$ (Grosse, 1890). Even a low estimate of 500 instruments made per year may therefore have consumed more than the above quantity of spar. Additionally, crystals and prisms were required for other purposes such as teaching and physics experiments.

Another view of the latter supply-demand enigma can be obtained from various publications between the 1880s and the 1910s. Throughout this period many users complained of a spar "famine" and "dearth", as indicated in Sect. 2 above (cf. Appendix 1A of Kristjánsson, 2010). The union of German instrument manufacturers even appealed twice in the late 1880s to the office of the Chancellor to do something about this grave situation (Haensch, 1889). According to Beckenkamp (1915) “...das zu grösseren Nicols brauchbare Material [ist] auf nur ... einen einzigen Kristallblock auf Island beschränkt...". In the same time interval, however, new polarized-light equipment kept appearing on the market, for instance from microscope makers like R. Fuess in Germany and A. Nachet in France (Groth, 1885, Anhang II, pp. 695-699). Various dealers also were advertising Iceland spar preparations; one brochure (Halle, ca. 1895) offers rhombohedra, plates, prisms, spheres, lenses, etc., in almost 200 shapes and sizes.
These apparent conflicts of evidence could be due to some large buyers of Iceland spar having built up their own stockpiles from the vigorous $1855-1873$ production efforts at Helgustaðir. Some material was also acquired by them from public and private collections (Beckenkamp, 1915). A distant possibility is that Iceland spar mines were operating at undisclosed locations in Europe or elsewhere. One should add that the businessmen leasing the Helgustaðir quarry in 1895-1910 were respected in Iceland for their fair practices, and it may be assumed that they reported to the authorities all the spar they were recovering and selling.

\section{Events after 1910}

Stocks of Iceland spar that had accumulated during the 18951910 operations were sold in 1910-1911. Quarrying at Helgustaðir was carried out until 1914 on behalf of a French company (Kristjánsson, 2003). In the final substantial effort of prospecting for optical-quality crystals which was organized by the Government in 1920-1924 (Eiríksson, 1920; Hagalín, 1970), several tons were recovered for export. Operations then ceased, after supplies began arriving in Europe from South Africa. Iceland spar localities were subsequently discovered in other parts of the world including Mexico, Siberia, China and Brazil. Polaroid foils which were first patented in 1933, provided a satisfactory substitute for Nicol prisms in a variety of situations. Nevertheless, complaints about the scarcity of good calcite crystals continued being voiced until at least 1950 (Kristjánsson, 2010, Appendix 1A). Iceland spar prisms are still an essential component in specialized optical devices, and spar samples for purposes such as mineral collections and science education are also available at moderate cost.

Considerable quantities of inferior material were collected from tailings at the Helgustaðir and Hoffell sites between 1933 and the 1950s, for use in a surface coating on concrete buildings, on walls around gardens and graves, etc. The Helgustaðir quarry has by now partially collapsed and no opticalquality spar is visible there in outcrops, but small pieces of calcite may be found lying about in the surrounding area. The site is protected by a Government declaration (Ministry of Education, 1975).

\section{Concluding remarks}

Many important advances in science in addition to those listed above, were prompted in part by results from research involving Iceland spar. All these advances have in turn led to progress in other fields of science, in technology and in medicine. One example is J. C. Maxwell's electromagnetic theory of the 1860s, whose conception owed much to the Faraday (1846) effect and to Maxwell's own experience with polarized light. As another example, the discovery of stress-induced birefringence in solids by Brewster (1816) 
and others gave rise to the field of photoelasticity, a valuable technique in 20th century mechanical engineering as well as in glass production. Characterization of the optical properties of surfaces and thin films (Tronstad, 1933) was essential in the development of modern electronic devices, and so was polarimetry in the pharmaceutical industry. Several Nobel laureates in physics and chemistry who carried out experiments with crystals or prisms of Iceland spar have been mentioned above; names of many others may be added, cf. Appendix 5 of Kristjánsson (2010). It is difficult to escape the conclusion that the existence of this small and remote source of crystals at Helgustaðir speeded up - even by decades - the worldwide development of numerous sectors of the physical and natural sciences, and their practical application.

After a long period of neglect, the historical importance of the Helgustaðir site is now gradually being recognized by local and national authorities. It ought to be preserved as a monument to the invaluable role played by minerals in the creation of modern society. Opportunities await those wishing to utilize the unique legacy of Iceland spar, within such diverse spheres of activity as the tourist trade in Iceland, arts and design, history of science, and television.

Acknowledgements. The author wishes to thank the reviewers and editors of the journal for valuable suggestions.

Edited by: J. M. Herndon

Reviewed by: D. Aquilano and another anonymous referee

\section{References}

Albert, J. W.: Apparate zu Versuchen über die Polarisation des Lichts, Trommsdorff's Neues J. Pharm., 16, 290-293, 1828.

Arrhenius, S.: Über die Reaktionsgeschwindigkeit bei der Inversion von Rohrzucker durch Säuren, Z. Phys. Chem, 4, 226-248, 1889.

Balmer, J.: Notiz über die Spektrallinien des Wasserstoffs, Verh. Naturf. Ges. Basel, 7, 548-553, 750-752, 1885.

Bartholin, R.: Experimenta Crystalli Islandici Disdiaclastici Quibus Mira \& Insolita Refractio Detegitur, D. Paulli, Copenhagen, 60 pp., 1669.

Bates, F. J. and Associates: Polarimetry, Saccharimetry and the Sugars, National Bureau of Standards Circular C440, Washington D.C., 810 pp., 1942.

Beckenkamp, J.: Statische und Kinetische Kristalltheorien, Zweiter Teil, Gebr. Borntraeger, Berlin, 670 pp., 1915.

Becquerel, A.: Recherches sur le pouvoir moléculaire rotatoire de l'albumine du sang et des liquids organiques, C. R. Acad. Sci., 29, 625-629, 1849.

Beer, A.: Bestimmung der Absorption des rothen Lichts in farbigen Flüssigkeiten, Ann. Phys. Leipzig, 86, 78-88, 1852.

Bernhardi, J. J.: Darstellung einer neuen Methode, Krystalle zu beschreiben, Gehlen's J. Chem. Phys. Mineral., 5, 157-198, 492564, 625-654, 1808.

Billet, F.: Traité d'Optique Physique I-II, Mallet-Bachelier, Paris, $540+640$ pp., $1858-1859$.
Biot, J. B.: Sur les rotations que certaines substances impriment aux axes de la polarisation des rayons lumineux, Mém. Acad. Sci., 2, 41-136, 1817.

Biot, J. B.: Sur l'emploi des caractères optiques, comme diagnostic immédiat du diabète sucré, C. R. Acad. Sci., 11, 1028-1035, 1840.

Borrmann, G.: Die Absorption von Röntgenstrahlen im Fall der Interferenz, Z. Phys., 127, 297-333, 1950.

Bragg, W. H.: X-rays and crystal structure, Philos. T. Roy. Soc. A, 215, 253-274, 1915.

Brauns, R.: Das Mineralreich, F. Lehmann, Stuttgart, 440 pp., 1903.

Bréon, R.: Rapport sur une mission en Islande, Arch. Miss. Sci. Litt., 8, 101-118, 1882.

Brewster, D.: On the communication of the structure of doublyrefracting crystals to glass, muriate of soda, fluor spar and other substances by mechanical compression and dilatation, Philos. T. Roy. Soc., 106, 157-178, 1816.

Brewster, D.: On the connection between the primitive forms of crystals, and the number of their axes of double refraction, Mem. Wernerian Nat. Hist. Soc., 3, 50-74, 337-350, 1819.

Compton, A. H.: A recording X-ray spectrometer, and the high frequency spectrum of tungsten, Phys. Rev., 7, 646-652, 1916.

Davis, B. and Terrill, H. M.: The refraction of X-rays in calcite, P. Natl. Acad. Sci. USA, 8, 357-361, 1922.

Dove, H. W.: Beschreibung eines Apparats für geradlinige, elliptische und circulare Polarisation des Lichtes, Ann. Phys. Leipzig, 35, 596-608, 1835.

Drude, P.: Lehrbuch der Optik, S. Hirzel Verlag, Leipzig, 498 pp., 1900.

Duparc, L. and Pearce, F.: Traité de Technique Minéralogique et Pétrographique, Première Partie, Veit \& Co., Leipzig, 483 pp., 1907.

Ehrenberg, C. G.: Über eine neue einflussreiche Anwendung des polarisirten Lichtes für mikroskopische Auffassung des Organischen und Anorganischen, Ber. K. Preuss. Akad., 238-247, 1848.

Eiríksson, H. H.: The spar-mine at Helgustadir, Iceland, Trans. Inst. Mining Eng., 59, 56-63, 1920.

Faraday, M.: Experimental researches in electricity, nineteenth series, Philos. T. Roy. Soc., 136, 1-20, 1846.

Fischer, E.: Untersuchungen über Aminosäuren, Polypeptide und Proteine, J. Springer, Berlin, 770 pp., 1906.

Fresnel, A.: Mémoire sur la double réfraction, Mém. Institut, 7, 45176, 1827.

Grosse, W.: Ueber Polarisationsprismen, Z. Instrumentenkd., 10, 445-446, 1890.

Groth, P.: Physikalische Kristallographie, 2nd Edn., editd by: Engelmann, W., Leipzig, 710 pp., 1885.

Grubenmann, U.: Einige Methoden und Ziele der neueren Petrographie, Verh. Schweiz. Naturf. Ges., 70, 7-22, 1887.

Haensch, H.: Die Schwierigkeiten bei Beschaffung von Doppelspath, Z. Instrumentenkd., 9, 391-393, 1889.

Hagalín, G. G.: Eldur er Beztur (Biography of the mining engineer H.H. Eiríksson; in Icelandic), Iðunn, Reykjavík, 283 pp., 1970.

Halle, B.: Preis-Liste von Bernhard Halle Optische Werkstatt, Steglitz/Berlin, 19 pp., ca. 1895.

Haüy, R. J.: Essai d'une Théorie sur la Structure des Crystaux, Gogué \& Née, Paris, 236 pp., 1784.

Hjaltalín, J.: Frumvarp (A motion proposing legislation to prohibit export of Iceland spar and other calcareous materials), 
Alpingistíðindi, part II, 296-298, 1875 (in Icelandic).

Huggins, W.: On the photographic spectra of stars, Philos. T. Roy. Soc., 171, 669-690, 1880.

Hughes, H. H.: Iceland spar and other crystals of related use, in: Industrial Minerals and Rocks, edited by: Dolbear, S. H., AIME, New York, 389-394, 1937.

Huygens, C.: Traité de la Lumière, P. van der Aa, Leiden, 125 pp., 1690.

Irby, J. R. M.: On the Crystallography of Calcite (dissertation, Göttingen), v. Marcus, Bonn, 72 pp., 1878.

Kerr, J.: A new relation between electricity and light: dielectrified media birefringent, Philos. Mag., 50, 337-348, 1875.

Kerr, J.: On the rotation of the plane of polarization by reflection from the pole of a magnet, Philos. Mag., 3, 321-343, 1877.

Kile, D. E.: The Petrographic Microscope. Evolution of a Mineralogical Research Instrument, The Mineralogical Record, Spec. Publ. No. 1, 96 pp., 2003.

Klockmann, F.: Lehrbuch der Mineralogie, 3rd Edn., F. Enke, Stuttgart, $588+41$ pp., 1903 .

Kristjánsson, L.: Iceland spar - the Helgustadir locality and its influence on the development of science, J. Geosci. Educ., 50, 419427, 2002

Kristjánsson, L.: A little known history of Helgustadir: type locality of Iceland spar, Matrix, 11, 95-107, http://www.raunvis.hi.is/ leo/greinar_pdf/Matrix.pdf, 2003.

Kristjánsson, L.: Iceland Spar and its Influence on the Development of Science and Technology in the Period 1780-1930, Report RH-20-2010, Science Institute, University of Iceland, Reykjavík, 400 pp., http://www.raunvis.hi.is/ leo/IcelandSpar14102010\% 20.pdf, 2010.

Landolt, H.: Das Optische Drehungsvermögen Organischer Substanzen und dessen Praktische Anwendungen, 2nd Edn., F. Vieweg \& Sohn, Braunschweig, 655 pp., 1898.

Lehmann, O.: Neue Untersuchungen über flüssige Kristalle I-III, Sitzber. Heidelb. Akad., 22. Abh., 42 pp., 1911, 13. Abh., 27 pp., 1912, and 13. Abh., 29 pp., 1913.

Leiss, C.: Die modernen Messinstrumente des Kristallographen und Petrographen, Fortschr. Mineral. Kristallogr. Petrogr., 10, 5-88, 1925.

Malus, E.: Théorie de la double réfraction, Mém. Savants Étr., 2, 303-508, 1811.

Martens, F. F. and Grünbaum, F.: Über eine Neukonstruktion des Königschen Spektralphotometers, Ann. Phys. Leipzig, 12, 984 1003, 1903

Mascart, E.: Sur les modifications qu'éprouve la lumière par suite du mouvement de la source lumineuse et du mouvement de l'observateur, Ann. Sci. École Norm. S., 1, 157-214, 1872.

Ministry of Education: Auglýsing (Declaration placing the Helgustaðir quarry and its immediate surroundings under protection), Stjórnartíðindi 1975, Series B, 1028-1029, 1975 (in Icelandic).

Mitchell, D. P.: Change of frequency of X-rays scattered by bound electrons, Phys. Rev., 33, 871-887, 1929.

Mitscherlich, E.: Über die Ausdehnung der krystallisirten Körper durch die Wärme, Abh. K. Preuss. Akad. 1825, 201-212, 1828.

Nicol, W.: On a method of so far increasing the divergency of the two rays in calcareous spar that only one image may be seen at a time, Edinb. New Philos. J., 6, 83-84, 1829.

Olavius, O.: Oeconomisk Reise igiennem de Nordvestlige, Nordlige og Nordostlige Kanter af Island (Travels in NW-, N- and NE-
Iceland in 1775-1777), Gyldendal, Copenhagen, 756 pp., 1780 (in Danish).

Osborn, S. J.: Chemical control in the beet sugar industry, J. Ind. Eng. Chem. U.S., 12, 803-805, 1920.

Pasteur, L.: Recherches sur les relations qui peuvent exister entre la forme cristalline, la composition chimique, et le sens du pouvoir rotatoire, Ann. Chim. Phys., 24, 442-459, 1848.

Pelouze, J. and Fremy, E.: Cours de Chimie Générale, Vol. 3, V. Masson, Paris, 950 pp., 1850.

Pickering, E. C., Searle, A., and Wendell, O. C.: Observations with the Meridian Photometer, Ann. Harvard Coll. Astron. Observ., 14, Part I, 324 pp., 1884.

Pringsheim, H.: Zuckerchemie, Akademische Verlagsgesellschaft, Leipzig, 322 pp., 1925.

Pritchard, A.: Microscopic Illustrations of Living Objects, 3rd Edn., Whittaker \& Co., London, 295 pp., 1845.

Reusch, E.: Über eine besondere Gattung von Durchgängen im Steinsalz und Kalkspath, Monatsber. Preuss. Akad. 1867, 220227,1868

Schiebold, E.: Die Verwendung der Lauediagramme zur Bestimmung der Struktur des Kalkspates, Abh. Math.-Phys. K1. Sächs. Akad., 36, 67-213, 1919.

Schmidt, W. J.: Die Bausteine des Tierkörpers in Polarisiertem Lichte, Fr. Cohen, Bonn, 528 pp., 1924.

Siegbahn, M.: Spektroskopie der Röntgenstrahlen, J. Springer, Berlin, 257 pp., 1924.

Struers, H.: Hovedprisliste (General catalog of scientific instruments and equipment), H. Struers Chemiske Laboratorium, Copenhagen, 448 pp., 1925 (in Danish).

Thoroddsen, T.: Ferðabók (Accounts of travels in Iceland in 1882-1898, by Iceland's first geologist), Vol. I, Hið íslenzka fræðafélag, Copenhagen, 380 pp., 1913 (in Icelandic).

Tronstad, L.: The investigation of thin surface films of metals by means of reflected polarized light, T. Faraday Soc., 29, 502-514, 1933.

Tschermak, G.: Über die Isomorphie der rhomboëdrischen Carbonate und des Natriumsalpeters, Mineral. Petrogr. Mitth., 4, 99121,1881

Tyndall, J.: On the blue colour of the sky, the polarization of skylight, and the polarization of light by cloudy matter generally, Philos. Mag., 37, 384-394, 1869.

Vogelsang, H.: Philosophie der Geologie und Mikroskopische Gesteinsstudien, Max Cohen \& Sohn, Bonn, 229 pp., 1867.

Walker, G. P. L.: Geology of the Reydarfjördur area, Eastern Iceland, Q. J. Geol. Soc. London, 114, 367-393, 1959.

Wanner, H.: Über einen Apparat zur photometrischen Messung hoher Temperaturen, Phys. Z., 3, 112-114, 1902.

Weigert, F.: Optische Methoden der Chemie, Akademische Verlagsgesellschaft, Leipzig, 632 pp., 1927.

Werner, A.: Zur Kenntnis des asymmetrischen Kobaltatoms I, Ber. Dtsch. Chem. Ges., 44, 1887-1898, 1911.

Wood, R. W.: Physical Optics, Macmillan Co., New York, 546 pp., 1905.

Young, T.: The Bakerian lecture on light and colours, Philos. T. Roy. Soc., 92, 12-48, 1802.

Zeeman, P.: On the influence of magnetism on the nature of the light emitted by a substance, Philos. Mag., 43, 226-239, 1897.

Zirkel, F.: Mikroskopische Gesteinsstudien, Sitzber. K. Akad. Wien, $47,226-270,1863$. 